\title{
Gambaran jumlah leukosit pada pasien infark miokard akut di RSUP Prof. Dr. R. D.Kandou Manado periode Januari-Desember 2015
}

\author{
${ }^{1}$ Ade M. Sitepu \\ ${ }^{2}$ Dewi U. Djafar \\ ${ }^{2}$ Agnes L. Panda
}

\author{
${ }^{1}$ Kandidat Skripsi Fakultas Kedokteran Universitas Sam Ratulangi Manado \\ ${ }^{2}$ Bagian Kardiologi Fakultas Kedokteran Unversitas Sam Ratulangi Manado \\ Email: ademarianathasitepu@gmail.com
}

\begin{abstract}
Coronary heart disease (CHD) is the leading cause of death in the world and marked by the existence of atherosclerotic plaque at the coronary artery that progressively blocks the blood stream to myocardium resulting in myocardial infarction. Elevated of leukocyte count typically indicates an infection or inflammation, and has a role in vascular injury and atherogenesis that is a development of an atherosclerotic ruptured plaque and trombosis. This study was aimed to obtain the profile of leukocyte count in patient with acute myocardial infarction (AMI) at Prof. Dr. R. D. Kandou Hospital Manado from January to December 2015. This was an observational descriptive study with a retrospective approach using data of medical records of AMI patients who came to Prof. Dr. R. D. Kandou Hospital Manado from January to Desember 2015. The results showed that of totally 63 medical records of patients with AMI, there were 45 samples that fulfilled the inclusion criteria. The majority patients were in the age group 46-60 years, males, the risk factor was a combination of several major risks, and NSTEMI as the type of type of infarction. There were $57,77 \%$ of leukocyte count results ranged $10,000-14,900 / \mathrm{mm}^{3}$ and $8,88 \%$ were $\geq 15,000 / \mathrm{mm}^{3}$. Conclusion: There was an increase in the leukocytes count in more than half of the samples.

Keywords: acute myocardial infarction, leukocyte, inflammation
\end{abstract}

\begin{abstract}
Abstrak: Penyakit jantung koroner (PJK) merupakan penyebab kematian tersering di dunia dan ditandai adanya plak aterosklerosis pada arteri koroner yang secara progresif menghalangi aliran darah ke miokardium yang berakibat terjadinya infark miokard. Peningkatan jumlah leukosit secara tipikal mengindikasikan adanya suatu infeksi dan peradangan, serta juga berperan pada cedera vaskular dan aterogenesis yang merupakan perkembangan dari suatu ruptur plak aterosklerosis dan trombosis. Penelitian ini bertujuan untuk mengetahui gambaran jumlah leukosit pada pasien IMA di RSUP Prof. Dr. R. D. Kandou periode Januari sampai Desember 2015. Jenis penelitian ialah deskriptif observasional dengan pendekatan retrospektif menggunakan data rekam medik pasien IMA yang berobat di RSUP Prof. Dr. R. D. Kandou Manado periode Januari-Desember 2015 dengan eksklusi riwayat infeksi minimal 2 minggu sebelum masuk rumah sakit. Hasil penelitian mendapatlan 45 sampel dengan mayoritas kelompok usia 46-60 tahun, jenis kelamin laki-laki, faktor risiko kombinasi beberapa faktor risiko mayor, dan jenis infark NSTEMI. Sebanyak $57,77 \%$ hasil pemeriksaan leukosit berkisar $10.000-14.900 / \mathrm{mm}^{3}$ dan $8,88 \%$ pada $\geq 15.000 / \mathrm{mm}^{3}$. Simpulan: Lebih dari setengah jumlah sampel mengalami peningkatan jumlah leukosit.
\end{abstract}

Kata kunci: infark miokard akut, leukosit, peradangan

Penyakit jantung koroner (PJK) merupakan penyebab kematian tersering di dunia dan ditandai dengan adanya aterosklerosis pada arteri koroner. Plak aterosklesrosis 
menutupi lumen arteri koroner secara progresif dan menghalangi aliran darah ke miokardium. Walaupun aterosklerosis merupakan suatu proses penyakit yang multifaktor, faktor inflamasi dan imunologi dianggap memiliki peran yang sangat penting. ${ }^{1}$ Angka kejadian penyakit Infark Miokard Akut (IMA) dapat diprediksi dengan melakukan pemeriksaan darah rutin yaitu leukosit pada saat pasien masuk rumah sakit. ${ }^{2}$

Peningkatan jumlah leukosit secara tipikal mengindikasikan adanya suatu infeksi dan peradangan, serta juga berperan pada cedera vaskular dan aterogenesis yang merupakan perkembangan dari suatu ruptur plak aterosklerosis, dan trombosis. ${ }^{3}$ Adanya jaringan infark menimbulkan reaksi peradangan pada daerah perbatasan antara jaringan infark dengan jaringan hidup. ${ }^{4}$ Jumlah leukosit yang tinggi berkaitan dengan luas infark yang terjadi, gangguan fungsi ventrikel kiri dan kematian setelah IMA. Proses peradangan atau inflamasi yang terjadi pada IMA sering ditandai dengan leukositosis perifer dan relatif paling sering adalah neutrofil. ${ }^{2}$

Penduduk Amerika mengalami kejadian koroner dalam setiap 34 detik, dan setiap menit terdapat kematian dengan faktor yang sama. Terdapat kurang lebih 1,5 juta kejadian infark miokard dalam setiap tahun. Mortalitas karena infark akut kurang lebih 30\%, dengan lebih dari separuh kematian terjadi sebelum individu yang terserang mencapai rumah sakit., ${ }^{5,6}$ Hasil Riskesdas pada tahun 2013 menunjukkan bahwa prevalensi penyakit jantung koroner berdasarkan wawancara terdiagnosis dokter di Indonesia sebesar $0,5 \%$, dan berdasarkan terdiagnosis dokter atau gejala sebesar 1,5\%. Prevalensi jantung koroner berdasarkan terdiagnosis tertinggi Sulawesi Tengah $(0,8 \%)$ diikuti Sulawesi Utara, DKI Jakarta, Aceh masingmasing $0,7 \%$. Prevalensi PJK menurut diagnosis atau gejala tertinggi di Nusa Tenggara Timur $(4,4 \%)$, diikuti Sulawesi Tengah $(3,8 \%)$, Sulawesi Selatan $(2,9 \%)$, dan Sulawesi Barat $(2,6 \%){ }^{7}$
Penelitian ini bertujuan untuk mengetahui gambaran leukosit pada pasien infark miokard akut di RSUP Prof. Dr. R. D. Kandou Manado periode Januari sampai Desember 2015.

\section{METODE PENELITIAN}

Jensi penelitian ini ialah deskriptif observasional dengan pendekatan retrospektif menggunakan data rekam medik pasien IMA yang datang berobat di RSUP Prof. Dr. R. D. Kandou Manado periode Januari-Desember 2015. Penelitian dilakukan di Bagian Rekam Medik dan Cardiovascular and Brain Center (CVBC) RSUP Prof. Dr. R. D. Kandou Manado. Populasi penelitian ialah semua pasien yang terdiagnosis menderita IMA di RSUP Prof. Dr. R. D. Kandou Manado periode Januari-Desember 2015. Kriteria inklusi yaitu data rekam medik pasien IMA yang lengkap disertai hasil pemeriksaan leukosit sedangkan kriteria eksklusi yaitu data rekam medik pasien IMA dengan riwayat penyakit infeksi minimal 2 minggu sebelum masuk rumah sakit. Variabel penelitian ialah jumlah leukosit, usia, jenis kelamin, faktor risiko, dan jenis infark miokard akut. Data yang didapat dari rekam medik pasien diolah menggunakan aplikasi Microsoft Excel kemudian disajiakan dalam bentuk tabel, diagram dan tulisan.

\section{HASIL PENELITIAN}

Hasil penelitian tentang gambaran jumlah leukosit pada pasien Infark Miokard Akut (IMA) di RSUP Prof. Dr. R. D.Kandou Manado periode JanuariDesember 2015 disajikan dalam bentuk tabulasi, diagram, dan tulisan yang mencakup tentang karakteristik umur, jenis kelamin, faktor risiko, jenis infark, jumlah leukosit, nilai rata-rata, standar deviasi, nilai minimum dan maksimum dari 45 sampel yang memenuhi kriteria inklusi.

Tabel 1 menunjukkan bahwa frekuensi terbanyak pasien IMA berada pada kelompok usia 46-60 tahun sebanyak 20 orang $(44,44 \%)$. Selanjutnya terdapat pada kelompok umur 61-75 tahun sebanyak 19 
orang (42,22\%), kelompok umur 30-45 tahun sebanyak 5 orang $(11,11 \%)$, dan frekuensi paling sedikit terdapat pada kelompok usia $>75$ tahun sebanyak 1 orang $(2,22 \%)$.

Tabel 1. Distribusi frekuensi sampel penelitian berdasarkan usia

\begin{tabular}{ccc}
\hline Usia (tahun) & Frekuensi & \% \\
\hline $30-45$ & 5 & 11,11 \\
$46-60$ & 20 & 44,44 \\
$61-75$ & 19 & 42,22 \\
$>75$ & 1 & 2,22 \\
Total & 45 & 100 \\
\hline
\end{tabular}

Tabel 2 menunjukkan bahwa frekuensi terbanyak pasien IMA berjenis kelamin laki-laki sebanyak 34 orang $(75,55 \%)$.

Tabel 2. Distribusi frekuensi sampel penelitian berdasarkan jenis kelamin

\begin{tabular}{ccc}
\hline Jenis kelamin & Frekuensi & \% \\
\hline Laki-Laki & 34 & 75,55 \\
Perempuan & 11 & 24,44 \\
\hline Total & 45 & 100 \\
\hline
\end{tabular}

Tabel 3 menunjukkan bahwa frekuensi terbanyak pasien IMA ialah dengan kombinasi beberapa faktor risiko mayor yaitu sebanyak 22 orang $(48,88 \%)$ sedangkan frekuensi pasien IMA dengan masing-masing faktor risiko mayor tersebut terbanyak ialah hipertensi $(22,22 \%)$, DM $(2,22 \%)$, hiperkolesterolemia $(6,66 \%)$, dan merokok $(4,44 \%)$. Didapatkan pula 7 orang $(15,55 \%)$ pasien IMA tanpa keempat faktor risiko mayor tersebut.

Tabel 3. Distribusi frekuensi sampel penelitian berdasarkan faktor risiko

\begin{tabular}{ccc}
\hline Faktor risiko & Frekuensi & \% \\
\hline Hipertensi & 10 & 22,22 \\
Diabetes Melitus (DM) & 1 & 2,22 \\
Hiperkolesterolemia & 3 & 6,66 \\
Merokok & 2 & 4,44 \\
Kombinasi beberapa & 22 & 48,88 \\
faktor risiko & & \\
Tidak ada Faktor & 7 & 15,55 \\
Risiko Mayor & & \\
Total & 45 & 100 \\
\hline
\end{tabular}

Berdasarkan Tabel 4 dapat dilihat bahwa frekuensi terbanyak pasien IMA menurut diagnosis ditemukan tanpa adanya elevasi ST sebanyak 37 orang $(82,22 \%)$, sedangkan pasien IMA menurut diagnosis ditemukan dengan adanya elevasi ST sebanyak 8 orang $(17,77 \%)$.

Tabel 4. Distribusi frekuensi sampel penelitian berdasarkan jenis infark

\begin{tabular}{ccc}
\hline $\begin{array}{c}\text { Klasifikasi } \\
\text { IMA }\end{array}$ & Frekuensi & \% \\
\hline STEMI & 8 & 17,77 \\
NSTEMI & 37 & 82,22 \\
\hline Total & 45 & 100 \\
\hline
\end{tabular}

Tabel 5 menunjukkan bahwa frekuensi terbanyak pasien IMA berada pada kelompok jumlah leukosit 10.000$14.900 / \mathrm{mm}^{3}$ yaitu sebanyak 26 orang $(57,77 \%)$ dengan rerata $12294,61 / \mathrm{mm}^{3}$. Selanjutnya terdapat pada kelompok jumlah leukosit $<10.000 / \mathrm{mm}^{3}$ sebanyak 15 orang $(33,33 \%)$ dengan rerata $7750,4 / \mathrm{mm}^{3}$; dan pada kelompok jumlah leukosit $\geq 15.000 / \mathrm{mm}^{3}$ sebanyak 4 orang $(8,88 \%)$ dengan rerata $19600,5 / \mathrm{mm}^{3}$.

Tabel 5. Distribusi frekuensi sampel penelitian berdasarkan jumlah leukosit

\begin{tabular}{cccc}
\hline $\begin{array}{c}\text { Jumlah } \\
\text { leukosit } \\
\left(\mathbf{m m m}^{3}\right)\end{array}$ & Frekuensi & $\%$ & $\begin{array}{c}\text { Rerata } \\
\text { leukosit } \\
\left(\mathbf{m m m}^{\mathbf{3}}\right)\end{array}$ \\
\hline$<10.000$ & 15 & 33,33 & 7750,4 \\
$10.000-14.900$ & 26 & 57,77 & 12294,61 \\
$\geq 15.000$ & 4 & 8,88 & 19600,5 \\
Total & 45 & 100 & 11429,29 \\
\hline
\end{tabular}

Tabel 6 menunjukkan bahwa frekuensi terbanyak pasien IMA dengan elevasi ST berada pada kelompok jumlah leukosit $<10.000 / \mathrm{mm}^{3}$ dan pada kelompok jumlah leukosit $10.000-14.900 / \mathrm{mm}^{3}$ yakni masingmasing kelompok sebanyak 3 orang $(37,5 \%)$ dengan rerata jumlah leukosit $6869 / \mathrm{mm}^{3}$ dan $13166,66 / \mathrm{mm}^{3}$. Selanjutnya terdapat pada kelompok jumlah leukosit $\geq 15.000 / \mathrm{mm}^{3}$ sebanyak 2 orang $(25 \%)$ dengan rerata $16050 / \mathrm{mm}^{3}$. 
Tabel 6. Distribusi frekuensi subjek berdasarkan Jumlah Leukosit pada STEMI

\begin{tabular}{cccc}
\hline $\begin{array}{c}\text { Jumlah } \\
\text { Leukosit } \\
\left(/ \mathbf{m m}^{3}\right)\end{array}$ & Frekuensi & $\%$ & $\begin{array}{c}\text { Rerata } \\
\text { Leukosit } \\
\left(\mathbf{m m m}^{3}\right)\end{array}$ \\
\hline$<10.000$ & 3 & 37,5 & 6869 \\
$10000-$ & 3 & 37,5 & 13166,6 \\
14.900 & 2 & 25 & 16050 \\
$\geq 15.000$ & & & \\
Total & 8 & 100 & 11525,8 \\
\hline
\end{tabular}

Tabel 7 menunjukkan bahwa frekuensi terbanyak pasien IMA tanpa adanya elevasi ST berada pada kelompok jumlah leukosit $10.000-14.900 / \mathrm{mm}^{3}$ yaitu sebanyak 23 orang $(62,16 \%)$ dengan rerata $12180,86 / \mathrm{mm}^{3}$. Selanjutnya terdapat pada kelompok jumlah leukosit $<10.000 / \mathrm{mm}^{3}$ sebanyak 12 orang $(32,43 \%)$ dengan rerata $7970,75 / \mathrm{mm}^{3}$; dan pada kelompok jumlah leukosit $\geq 15.000 / \mathrm{mm}^{3}$ sebanyak 2 orang $(5,4 \%)$ dengan rerata $23151 / \mathrm{mm}^{3}$.

Berdasarkan Tabel 8 dapat dilihat bahwa rerata jumlah leukosit dari 45 pasien IMA ialah $11429,28 / \mathrm{mm}^{3}$ dengan standar deviasi sebesar 4052,23; nilai minimum leukosit $5710 / \mathrm{mm}^{3}$ dan maksimum $30700 / \mathrm{mm}^{3}$.

Tabel 7. Distribusi frekuensi subjek berdasarkan jumlah leukosit pada NSTEMI

\begin{tabular}{cccc}
\hline $\begin{array}{c}\text { Jumlah } \\
\text { Leukosit } \\
\left(\mathbf{m m}^{3}\right)\end{array}$ & Frekuensi & $\%$ & $\begin{array}{c}\text { Rerata } \\
\text { Leukosit } \\
\left(\mathbf{~ m m}^{3}\right)\end{array}$ \\
\hline$<10.000$ & 12 & 32,43 & 7970,75 \\
$10000-$ & 23 & 62,16 & 12180,86 \\
14.900 & 2 & 5,4 & 23151 \\
$\geq 15.000$ & & & \\
Total & 37 & 100 & 11408,4 \\
\hline
\end{tabular}

Tabel 8. Nilai rerata, standar deviasi, minimum dan maksimum leukosit

\begin{tabular}{cccc}
\hline Rerata & SD & Min & Maks \\
\hline 11429.28 & 4052.23 & 5710 & 30700 \\
\hline
\end{tabular}

\section{BAHASAN}

Populasi pasien IMA yang dirawat inap di CVBC RSUP. Prof. Dr. R. D. Kandou selama periode Januari-Desember 2015 sebanyak 63 pasien, namun yang memenuhi kriteria inklusi penelitian ini hanya sebanyak 45 pasien. Dari 45 pasien tersebut didapatkan terbanyak berada pada kelompok usia 46-60 tahun yakni sebanyak 20 orang. Hal ini sesuai dengan penelitian yang dilakukan Lamuna et al. ${ }^{8}$ pada pasien IMA di RSUP M. Djamil Padang periode 1 Januari-31 Desember 2012 yang mendapatkan penderita terbanyak pada kelompok usia 45-59 tahun $(51,72 \%){ }^{8}$ Angka kejadian IMA dipengaruhi oleh usia. Usia yang lebih tua dikaitkan dengan perubahan fisiologis dan struktur kardiovaskular yang terjadi secara bermakna, termasuk adanya kelainan fungsi diastolik ventrikel kiri, penurunan kompliansi vaskular sistemik, peningkatan indeks massa ventrikel kiri, perubahan neurohormonal dan pengaruh otonom. Demikian pula seiring bertambahnya usia terjadi peningkatan yang lebih besar pada faktor koagulasi (VII, VIII, dan IX) dibandingkan dengan faktor antikoagulan (antitrombin III, protein $\mathrm{C}$, dan protein $\mathrm{S}$ ), sehingga meningkatkan risiko terjadinya trombosis pada pasien usia lanjut. ${ }^{9}$

Berdasarkan penelitian dapat dilihat bahwa frekuensi terbanyak pasien IMA ialah laki-laki, yakni sebanyak 34 orang $(75,55 \%)$ sedangkan yang berjenis kelamin perempuan hanya sebanyak 11 orang $(24,44 \%)$. Hal ini sejalan dengan penelitian Brian et al. yang mendapatkan laki-laki $(74,9 \%)$ lebih banyak mengalami infark miokard daripada perempuan $(25,1 \%)$. Berdasarkan penelitian-penelitian epidemiologis prospektif, diketahui bahwa laki-laki mempunyai risiko penyakit jantung lebih tinggi daripada perempuan dan ketika menopause perempuan menjadi sama rentannya dengan laki-laki. Hal ini diduga karena adanya efek perlindungan estrogen. ${ }^{10}$

Hasil penelitian menunjukkan bahwa frekuensi terbanyak pasien IMA ialah dengan kombinasi beberapa faktor risiko mayor yaitu sebanyak 22 orang $(48,88 \%)$ sedangkan frekuensi pasien penderita IMA dengan faktor risiko tunggal terbanyak ialah hipertensi yakni 10 orang $(22,22 \%)$. Dari beberapa penelitian Framingham 1965 
didapatkan sekitar $50 \%$ penderita infark miokard menderita hipertensi dan $75 \%$ kegagalan ventrikel kiri dengan penyebab hipertensi. Tekanan darah yang tinggi dan menetap akan menimbulkan trauma langsung terhadap dinding pembuluh darah arteri koronaria dan memudahkan terjadinya aterosklerosis koroner. Hal ini mengakibatkan infark miokard lebih sering didapatkan pada penderita hipertensi dibandingkan orang normal. ${ }^{11}$

Hasil penelitian ini juga memperlihatkan faktor risiko lain seperti hiperkolesterolemia, DM dan merokok. Dari 45 pasien IMA terdapat 7 orang yang tidak memiliki faktor risiko mayor. Menurut Jneid, ${ }^{12}$ mortalitas akibat PJK 3-7 kali lebih tinggi pada perempuan dengan diabetes dibandingkan laki-laki dengan diabetes. Penyandang diabetes melitus cenderung untuk mengalami aterosklerosis pada usia yang lebih dini dan penyakit yang ditimbulkan lebih cepat dan lebih berat dari pada non-diabetes. ${ }^{12}$ Jenis kelamin menurut kejadian tertinggi terdapat pada laki-laki, yakni pada pasien dengan riwayat merokok, hiperkolesterolemia, dan hipertensi yang memiliki risiko besar untuk menderita PJK. ${ }^{13}$

Berdasarkan hasil penelitian frekuensi terbanyak pasien IMA menurut diagnosis yang ditemukan tanpa adanya elevasi ST (NSTEMI) sebanyak 37 orang $(82,22 \%)$ sedangkan frekuensi pasien penderita IMA menurut diagnosis dengan adanya elevasi ST (STEMI) sebanyak 8 orang $(17,77 \%)$. Hal ini sejalan dengan penelitian Nuniz et al. ${ }^{14}$ yang melakukan penelitian terhadap 1118 pasien terdiagnosis IMA dan mendapatkan 569 pasien NSTEMI dan 549 pasien STEMI. Dalam penelitian Manus et al. ${ }^{15}$, tingkat kejadian STEMI menurun secara signifikan antara tahun 1997 sampai tahun 2005 sedangkan tingkat kejadian NSTEMI meningkat secara tajam selama periode tersebut karena adanya pengenalan terhadap biomarker high-sensitivity.

Hasil penelitian menunjukkan frekuensi terbanyak pasien IMA berada pada kelompok jumlah leukosit 10.000$14.900 / \mathrm{mm}^{3}$ yaitu sebanyak 26 orang
$(57,77 \%)$ dengan rerata $12294,61 / \mathrm{mm}^{3}$. Selanjutnya terdapat pada kelompok jumlah leukosit $<10.000 / \mathrm{mm}^{3}$ sebanyak 15 orang $(33,33 \%)$ dengan rerata $7750,4 / \mathrm{mm}^{3}$; dan pada kelompok jumlah leukosit $\geq$ $15.000 / \mathrm{mm}^{3}$ sebanyak 4 orang $(8,88 \%)$ dengan rerata $19600,5 / \mathrm{mm}^{3}$. Berdasarkan pemeriksaan laboratorium di RSUP Prof. Dr. R. D. Kandou Manado yang menggunakan nilai normal jumlah leukosit 4.000$10.000 / \mathrm{mm}^{3}$, maka total pasien dengan peningkatan jumlah leukosit (leukositosis) ialah 30 orang $(66,66 \%)$ dan dengan jumlah leukosit normal ialah 15 orang $(33,33 \%)$.

Frekuensi pasien dominan mengalami peningkatan jumlah leukosit terjadi pada kedua jenis infark, yakni STEMI dan NSTEMI. Nuniz et al. ${ }^{14}$ membagi range jumlah leukosit menjadi 3 kelompok, yaitu: kelompok 1 dengan jumlah leukosit $<10.000 / \mathrm{mm}^{3}$, kelompok 2 dengan jumlah leukosit $10.000-14.900 / \mathrm{mm}^{3}$, dan kelompok 3 dengan jumlah leukosit $\geq 15.000 / \mathrm{mm}^{3}$. Pemeriksaan leukosit dilakukan dalam 24 jam setelah pasien diterima. Hasil penelitian menunjukkan bahwa pada kasus NSTEMI dan STEMI, peningkatan jumlah leukosit dominan berada pada kelompok 2 dan 3 .

Proses inflamasi menunjukkan peranan penting dalam kejadian kardiovaskular. Meskipun mekanisme yang bertanggung jawab dalam hal ini belum diketahui, namun beberapa hipotesis sudah dimunculkan, antara lain ialah leukocytemediated hypercoagulable state, leukocytemediated no-reflow, dan kardiotoksik yang secara tidak langsung dimediasi oleh sitokin-sitokin proinflamasi. Peningkatan jumlah leukosit dihubungkan dengan berkurangnya aliran darah epikardium dan perfusi miokard, pembentukan trombus yang lebih besar pada area plak yang ruptur, membuat peningkatan jumlah leukosit menjadi penanda adanya hiperkoagulasi atau tromboresistensi. Beberapa penelitian juga telah menunjukkan bahwa respons inflamasi sistemik terjadi pada pasien IMA dan juga bahwa plasma dari pasien IMA mampu menstimulasi IL-6 dan IL-8 pada leukosit. ${ }^{16}$

Pada jaringan infark akan terjadi reaksi 
radang antara jaringan infark dengan jaringan hidup. ${ }^{4}$ Hal tersebut mengakibatkan terjadinya peningkatan jumlah leukosit pada jaringan infark, terutama neutrofil akibat mobilitas tinggi namun dalam penelitian ini sangat sedikit didapatkan hasil pemeriksaan hitung jenis leukosit pada rekam medik, sehingga tidak mampu menggambarkan perbedaan yang jelas pada jenis leukosit.

Menurut Kurniawan et al. $^{17}$ pasien dengan leukositosis secara bermakna memiliki risiko mortalitas 10,71 kali dibandingkan pasien dengan jumlah leukosit normal. Tidak terdapat sampel penelitian yang masuk rumah sakit dengan leukopenia. ${ }^{17}$

\section{SIMPULAN}

Berdasarkan hasil penelitian terhadap 45 jumlah sampel data rekam medik pasien IMA di CVBC RSUP Prof. Dr. R. D. Kandou Manado periode Januari-Desember 2015 didapatkan mayoritas pasien IMA ialah pada kelompok usia 46-60 tahun, lakilaki, dan dengan faktor risiko berupa kombinasi beberapa faktor risiko mayor. Jenis infark yang paling banyak ditemukan ialah NSTEMI dengan lebih dari setengah jumlah sampel mengalami peningkatan jumlah leukosit.

\section{SARAN}

Untuk institusi rekam medik agar dapat memaksimalkan proses penyimpanan data sehingga dapat mempermudah penelitian selanjutnya.

Untuk penelitian selanjutnya agar dapat meneliti lebih lanjut tentang hubungan peningkatan leukosit dengan usia, jenis kelamin, dan faktor risiko dari IMA.

Untuk masyarakat agar dapat menjalani gaya hidup yang sehat agar terhindar dari faktor risiko terjadinya penyakit jantung koroner (PJK).

\section{DAFTAR PUSTAKA}

1. Ozdemir S, Barutcu A, Turkon H, et al. The relationship between some complete blood count parameters and myocardial perfusion: a scintigraphic approach. World J Nucl Med. 2015. Available from

URL:

http://www.ncbi.nim.nih.gov/pmc/articl es/PMC4564923/\#lpo=10.0000

2. Rohani A, Akbari V, Moradian K, Malekzade J. Combining white blood cell count and thrombosis for predicting in-hospital outcomes after acute myocardial infarction. J Emergency, Trauma, and Shock. 2011;3:351-4.

3. Grzybowski M, Welch RD, Parsons L, Ndumele CE, Chen E, Zalenski R, et al. The association between WBC and AMI in hospital mortality: findings from the National Registry of Myocardial Infarction. Academic Emergency Medicine. 2004;11(10: 1049-60.

4. Price SA, Wilson LM. Patofisiologi. In: Pendit BU, Hartanto H, Wulansari P, Mahanani DA, transl. Konsep Klinis Proses-proses Penyakit Vol 1 (6th ed). Jakarta: EGC, 2005.

5. Ferrari JP, Lueneberg ME, Silva RL, Fattah T, Gottschall CA, Moreira DM. Correlation between leukocyte count and infarct size in ST segment elevation myocardial infarction. Arch Med Sci Atjeroscler Dis. 2016;1:e44e48.

6. Isselbachr KJ, Braunwald G, Wilson JD, Martin BJ, Fauci AS, Kasper DL. Harison Prinsip-prinsip Ilmu Penyakit Dalam (13th ed). Asdie AH, transl. Jakarta; EGC, 2000.

7. Kementerian Kesehatan RI. Badan Litbangkes Kementerian Kesehatan RI dan Data Penduduk Sasaran. Data Riset Kesehatan Dasar 2013. Available from: http://www.depkes.go.id/resources/dow nload/general/Hasil\%20Riskesdas\%20 2013.pdf

8. Lamuna F, Edward Z, Rasyid R. Gambaran profil lipid pada pasien infark miokard akut di RSUP M. Djamil Padang Periode 1 Januari 2011 - 31 Desember 2012. Jurnal Kesehatan Andalas. 2015: 4(2).

9. Mehta RH, Rathore SS, Radford MJ, Wang Y, Krumholz HM. Acute myocardial infarction in the elderly: differences by age. J Am Coll Cardiol. 2001; 38(3). Available from: http://content.onlinejacc.org/ 
10. Susilo C. Identifikasi faktor usia, jenis kelamin dengan luas infark miokard pada penyakit jantung koroner di ruang ICCU RSD Dr. Soebandi Jember. The Indonesian Journal of Health Science. 2015;6(1).

11. Universitas Kristen Satya Wacana. Faktorfaktor risiko penyakit jantung koroner pada kelompok usia $=45$ Tahun di RS Panti Wilasa Citarum Semarang. Available from: http://repository.uksw.edu/bitstream/12 3456789/5312/3/T1_462007005_BAB \%20II.pdf

12. Jneid H, Thacker HL. Coronary artery disease in women: different undertreated review. Cleveland Clinic Journal of Medicine. 2001.;68(5): 4418.

13. Fiscella K, Franks P. Should years of schooling be used to guide treatment of coronary risk factors? US National Library of Medicine. 2004.2(5):469. Available from: https://www.ncbi.nlm.nih.gov/pubmed/ 15506583

14. Núñez J, Fácila L, Llàcer A, Sanchís
J, Bodí V, Bertomeu V. Prognostic value of white blood cell count in acute myocardial infarction: long-term mortality. US National Library of Medicine. 2005;58(6):631. Available from:

https://www.ncbi.nlm.nih.gov/pubmed/ 15970118

15. Manus DD, Gore J, Yarzebski J, Spencer F, Lessard D, Goldberg R. Recent trends in the incidence, treatment, and outcomes of patients with STEMI and NSTEMI. Am J Med. 2011;124:40-7.

16. Barron HV, Cannon CP, Murphy SA, Braunwald E, Gibson M. Association between white blood cell count, epicardial blood flow, myocardial perfusion, and clinical outcomes in the setting of acute myocardial infarction: a thrombolysis in myocardial infarction 10 sbstudy. Circulation. 2000;102(19): 2329-34.

17. Kurniawan LB, Bahrun U, Darmawaty ER, Arif M. Pengaruh jumlah leukosit terhadap mortalitas pasien infark miokard akut selama perawatan. CDK233. 2015;10:729. 